\section{MELHORIA E REENGENHARIA DE PROCESSOS EMPRESARIAIS FOCANDO O CLIENTE}

de NADIM MAHMOUD KAMEL

Säo Paulo: Érica, 1.ed., 1994, $136 \mathrm{p}$

por Antonio Jesus Brito Consenza, Professor do Departamento de Mercadologia da EAESP/FGV.

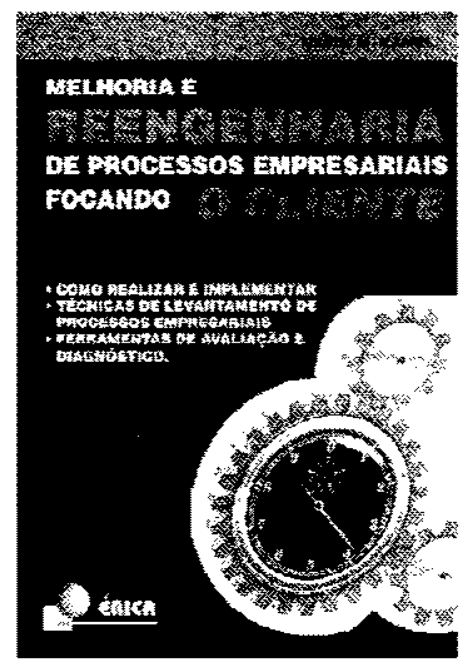

O autor consegue navegar pelo mundo das novas terminologias de administracão com facilidade tal, que permite ao leitor leigo ter uma compreensăo adequada das técnicas e passos necessários para tomar a sua empresa atualizada, aproveitando-se das ferramentas atuais para a obtenção de uma melhor produtividade, portanto, de uma melhor posiçăo no mercado, tanto no aspecto lucrativo como participativo.

No decorrer de catorze capitulos, o autor indica como aplicar uma reestruturaçâo organizacional e empresarial sem a necessidade de se recorrer a grandes empresas de consultoria empresarial e sem causar a traumática desmotivação no quadro funcional - que ele chama de colaboradores - decorrente da mudança inexorável e da redução dos quadros operacionais.

Sua metodologia, de uma lógica e simplicidade cristalinas, indica os passos a serem dados e a seqüencia mais adequada para que, ao final, todos os funcionários / colaboradores, possam estar envolvidos e compromissados com as metas traçadas.

Assim, a primeira atitude a ser tomada é a identificação do perfil dos executivos da empresa que, se for tradicional, levará o processo ao fracasso. Para que haja maior probabilidade de sucesso, os executivos devem ter: visão do negócio, clareza nos objetivos, comportamento ético, competência técnica e grande afinidade de negociaçāo, cultura geral em constante evolução, capacidade de administrar de forma participativa, facilidade de incentivar o diálogo, capacidade de aproveitar o potencial do quadro de talentos humanos e facilidade de incentivar a motivação e a didática da equipe.

Uma vez identificados executivos com esse perfil, a empresa pode dar início ao processo de implantação de qualidade, de reestruturação ou de reengenharia, sem perder de vista que os padrôes são estabelecidos pelos clientes, sejam estes o próprio mercado ou mesmo clientes individuais.
Tem início a definiçâo do negócio da empresa, ou seja, o ramo de atividade em que ela atua, de acordo com a percepçäo de valor agregado do cliente e näo daquele ditado pelo produto/serviço que a organização coloca à disposicăo do mercado. Do negócio, a empresa passa à definiçắo

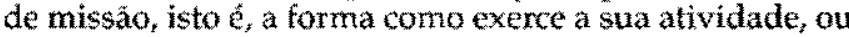
seja, comprando, produzindo, desenvolvendo, criando, comercializando, entregando etc.

A definição da missăo leva diretamente aos objetivos dispostos em escalas hierárquicas e ao estabelecimento de metas mensurâveis, apoladas por um tworkilan.

O proximo passo é conscientizar toda a organizaçăo a respeito das definiçōes anteriores. Só então é que se aplica a reengenharia ou a melhoria dos processos, que, por sua vez, tamberm envolve etapas que não podem ser ignoradas. Para entrar no método proposto de reengenharia, o autor define, entăo, o que são, no seu entendimento, um processo, uma tarefa, uma atividade, o custo do processo, o tempo de ciclo, o valor agregado, o ciclo de vida e os novos negócios.

Seu ponto de partida é representado pela definição e análise do processo a ser aperfeicoado. $O$ autor náo recomenda que se faça uma reengenharia parcial, em um único processo, porque, necessariamente, haverá impacto em outros processos da empresa. A definiçấo e a análise do processo constituem-se por 16 etapas exaustivamente descritas, de maneira prática e operacional, de forma a possibilitar a sua implantaçäo na empresa por todo pequeno e médio empresário.

Pontos-chave para a adminístraçăo da reengenharia/meIhoria dos processos sâo a escolha dos líderes-executivos que autorizam, motivam suportam o esforço global de reengenharia. Em sequência, temos os proprietários dos processos - responsáveis por processos específicos com pleno conhecimento - seguidos pelo coordenador da reengenharia - funcionário ou consultor com responsabilidade de desenvolver técnicas e ferramentas de avaliaçäo e diagnóstico. Chega-se ao momento da criaçăo de equipes multidisciplinares, ou células, compostas por pessoas que trabalham juntas de modo cooperativo. Todas as células estarâo ligadas ao comitê executivo - composto pelos líderes -, tendo o proprietário do processo como interface junto às células. $O$ aumento de complexidade é administrado pela criação de subprocessos que dão origem ao mesmo procedimento, multiplicado quantas vezes for necessário.

O método proposto pelo autor é complementado por algumas ferramentas de avaliaçăo e diagnóstico, como brainstorning, diagrama de afinidades e diagráfico de interrelacionamento, além de diagrama de causa e efeito, planilha de verificação, diagrama de Pareto e histograma de dispersăo dos dados de processo. Adicionalmente, apresenta-se a grande utilidade de uma E.D.I. (Electronic Data Interchange), intercàmbio eletrônico de dados que visa a reduzir tarefas e mesmo atividades por meio do transporte eficaz das informaçóes.

A conclusăo do autor nảo poderia ser mais motivadora para as empresas aplicarem sua metodologia, uma vez que, para ele, objetivo da melhoria ou reengenharia dos processos é "mudar o estado de ser das pessoas e a manema como elas devem trabahar, atraves da mudança da cultura do valores da organizaça, de uma forma gradativa e con a conscientizacuo dos funcionários de que a melhoria ea mudança irấ trazer beneficios a eles". 